\title{
Thyroid function in type 2 diabetes mellitus
}

\author{
Sajeda Afrin ${ }^{1}$, Chandra Rani Sarkar ${ }^{2}$, A.T.M Zoadur Rahim Zahid ${ }^{3}$, NeazAhmed ${ }^{4}$
}

\begin{abstract}
Background: Type 2 Diabetes Mellitus (T2DM) and thyroid disorder are common endocrine disorders that affect major population worldwide. Subclinical hypothyroidism is common among T2DM. Objectives: To observe thyroid stimulating hormone (TSH), total thyroxine $\left(\mathrm{TT}_{4}\right)$, free thyroxine $\left(\mathrm{FT}_{4}\right)$, total triiodothyronine $\left(\mathrm{TT}_{3}\right)$, free triiodothyronine $\left(\mathrm{FT}_{3}\right)$ levels in newly diagnosed T2DM. Methods: This cross sectional study was conducted from July 2014 to June 2015. For this, 50 newly diagnosed T2DM patients aged 30 to 50 years of both sexes were enrolled from the Out Patient Department of Endocrinology, Rangpur Medical College and Diabetic Association, Rangpur. Fifty age matched non-diabetic healthy subjects of both sexes constituted control. Serum TSH, TT $4, \mathrm{FT}_{4}, \mathrm{TT}_{3}$, $\mathrm{FT}_{3}$ levels were estimated to observe thyroid function. All these hormones were estimated by ELISA method. For statistical analysis independent sample " $t$ " test was performed. Results: Serum TSH was significantly higher $(\mathrm{p}<0.001)$ and serum $\mathrm{TT}_{4}, \mathrm{FT}_{4}, \mathrm{FT}_{3}$ levels were significantly lower $(\mathrm{p}<0.001)$ in T2DM compared to control. Eight (16\%) of T2DM were hypothyroid. Conclusion: From this study it can be concluded that altered thyroid status leading to hypothyroidism may be associated with T2DM.
\end{abstract}

Key word: Type 2 Diabetes Mellitus, $\mathrm{TSH}_{1} \mathrm{TT}_{4}, \mathrm{FT}_{4}, \mathrm{TT}_{3}, \mathrm{FT}_{3}$.

J Bangladesh Soc Physiol. 2017, December; 12(2): 61-64 For Authors Affiliation, see end of text.

http://www.banglajol.info/index.php/JBSP

\section{Introduction}

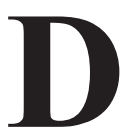

iabetes mellitus is a syndrome of impaired carbohydrate, fat and protein metabolism caused by either lack of insulin secretion or decreased sensitivity of the tissues to insulin ${ }^{1}$. Worldwide over 380 million people were estimated to have T2DM in $2013^{2}$. T2DM poses a major global health threat, both in the developed and developing countries ${ }^{3}$. Diabetes Mellitus and thyroid disorders are endocrine disorders that are interrelated to each other ${ }^{4}$. The relationship between Diabetes Mellitus and thyroid disorders is characterized by a complex interdependent interaction. A higher frequency of retinopathy, nephropathy,

Received 18 Oct. 2017; $\quad$ Accepted 29 Nov. 2017 cardiovascular diseases and also subclinical hypothyroidism complications were observed in $\mathrm{T}^{2} \mathrm{DM}^{5}$. Subclinical hypothyroidism being the most common disorder in $\mathrm{T}_{2} \mathrm{DM}^{6} . \mathrm{TT}_{4}, \mathrm{TT}_{3}$ secretion is controlled primarily by $\mathrm{TSH}$, secreted from anterior pituitary gland ${ }^{7}$. Thyroid hormones are necessary for normal glucose metabolism. Hyper or hypo secretion of thyroid hormones can alter glucose homeostasis ${ }^{5}$. Thyroid disorders not only worsen the metabolic control but also affect the management of diabetes ${ }^{8}$. Therefore, diabetes patients need to be screened for thyroid dysfunction. American diabetic Association (ADA) has proposed the people with diabetes to be checked for thyroid disorders ${ }^{9}$. The magnitude of health problems related to diabetes 
mellitus in our country has been increasing rapidly. Majority of the people are not aware about their health hazards caused by Diabetes Mellitus as well as thyroid dysfunction. Although thyroid disorders are increasing among T2DM but it is frequently overlooked and not diagnosed properly in the early stage. Only one study on hypothyroidism among T2DM is available ${ }^{10}$. Therefore, the present study has been designed to assess thyroid disorder among T2DM and thereby to develop awareness about thyroid dysfunction in newly diagnosed T2DM.

\section{Methods}

This is a cross sectional analytical study conducted in Department of Physiology, Rangpur Medical College, Rangpur from July, 2014 to June, 2015. Protocol of this study was approved by ethical review committee of Rangpur Medical College. A total number of 100 subjects, aged 30 to 50 years of both sexes and similar socio-economical condition were included in this study. Among them, 50 were apparently healthy subjects and 50 were newly diagnosed T2DM patients, selected from Out Patient Department (OPD) of Endocrinology, Rangpur Medical College and Diabetic Association, Rangpur. The objectives, nature, purpose and benefit of the study were explained to the subjects in details. Informed written consent was taken from all participants. All the subjects were excluded from known thyroid disorders, treated Type 2 Diabetes Mellitus and T2DM with other complications.

After 8-10 hours overnight fasting and 2 hours after ingestion of $75 \mathrm{gm}$ glucose, each time $5 \mathrm{ml}$ of venous blood was drawn from medial cubital vein by sterile disposable syringe. Serum glucose was estimated by enzyme method ${ }^{11}$. Serum TSH, $\mathrm{TT}_{4}, \mathrm{FT}_{4}, \mathrm{TT}_{3}$ and $\mathrm{FT}_{3}$ were estimatedby ELISA method $^{12}$. Data were expressed as mean $\pm \mathrm{SE}$ and were analyzed by independent sample ‘ $\mathrm{t}$ ' test. $\mathrm{p}$ value $<0.05$ was taken as level of significance.

\section{Results}

The mean serum TSH level was significantly higher $(\mathrm{p}<0.001)$ and the $\mathrm{TT}_{4}, \mathrm{FT}_{4}, \mathrm{TT}_{3}$ and $\mathrm{FT}_{3}$ levels were significantly lower $(p<0.001)$ in T2DM than those of non-diabetic group (Table I). Eight (16\%) patients were found with developing hypothyroid but none of control group had hypothyroidism (Figure 1).

Table I : Serum TSH, $\mathrm{TT}_{4}, \mathrm{FT}_{4}, \mathrm{~T}_{3}$ and $\mathrm{FT}_{3}$ levels in different groups $(\mathrm{n}=100)$

\begin{tabular}{lcc}
\hline Variables & NDG $(\mathrm{n}=50)$ & $\mathrm{DG}(\mathrm{n}=50)$ \\
\hline $\mathrm{TSH}(\mathrm{mIU} / \mathrm{L})$ & $3.04 \pm 0.08$ & $5.34 \pm 0.23^{* * *}$ \\
$\mathrm{TT}_{4}(\mu \mathrm{g} / \mathrm{dl})$ & $8.05 \pm 0.17$ & $3.91 \pm 0.15^{* * *}$ \\
$\mathrm{FT}_{4}(\mathrm{ng} / \mathrm{dl})$ & $1.56 \pm 0.05$ & $0.71 \pm 0.04^{* * *}$ \\
$\mathrm{TT}_{3}(\mathrm{ng} / \mathrm{ml})$ & $1.25 \pm 0.03$ & $0.80 \pm 0.02^{* * *}$ \\
$\mathrm{FT}_{3}(\mathrm{pg} / \mathrm{ml})$ & $3.28 \pm 0.03$ & $2.59 \pm 0.07^{* * *}$ \\
\hline
\end{tabular}

Data were expressed as mean \pm SE. Statistical analysis was done by independent sample ' $t$ ' test for comparison between groups. $* * *=p<0.001$. $\mathrm{TSH}=$ Thyroid Stimulating Hormone. $\mathrm{TT}_{4}=$ Total Thyroxine. $\mathrm{TT}_{3}=$ Total Triiodothyronine. $\mathrm{FT}_{4}=$ Free Thyroxine. $\mathrm{FT}_{3}=$ Free Triiodothyronine. $\mathrm{NDG}=$ Non-diabetic group, $\mathrm{DG}=$ Diabetic Group.

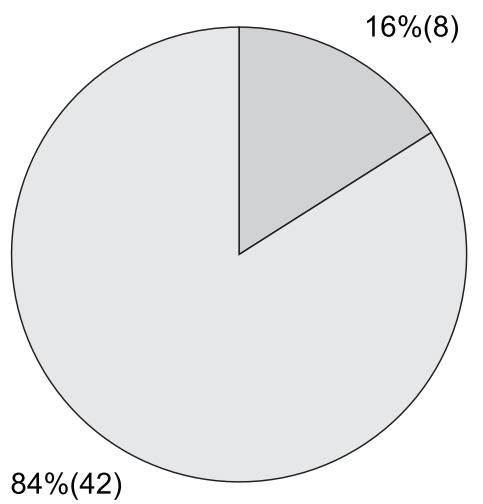

Figure 1: Pie chart showing the frequency of hypothyroidism (in \%) in diabetic group. Cut point for $\mathrm{TT}_{4}=4.4-10.8 \mu \mathrm{g} / \mathrm{dl}^{20}, \mathrm{TT}_{3}=0.69-2.02 \mathrm{ng} / \mathrm{ml}^{20}$, $\mathrm{FT}_{4}=0.8-2.0 \mathrm{ng} / \mathrm{dl}^{20}, \mathrm{FT}_{3}=1.4-4.2 \mathrm{pg} / \mathrm{ml}^{21}$, $\mathrm{TSH}=0.3-6.2 \mathrm{mIU} / \mathrm{L}^{20}$ 


\section{Discussion}

In the present study, serum TSH level was found significantly increased but serum $\mathrm{TT}_{4}, \mathrm{FT}_{4}, \mathrm{TT}_{3}$ and $\mathrm{FT}_{3}$ levels were found significantly decreased in newly diagnosed T2DM than that of control subjects. Moreover, $16 \%$ of the patients presented with hypothyroid status. This finding is consistent with others ${ }^{3,8,10,13}$. In contrast, some other researchers did not find any significant change of serum TSH in T2 $\mathrm{DM}^{14}$.Even some studies found lower levels of serum TSH and higher levels of serum $\mathrm{TT}_{4}$ and $\mathrm{TT}_{3}$ in $\mathrm{T} 2 \mathrm{DM}$ than that of control group ${ }^{15,16}$.

It has been suggested that altered thyroid status in T2DM is linked toleration of hypothalamopituitary-thyroid axis causing decreased formation of $\mathrm{TT}_{4}$ and $\mathrm{TT}_{3}$. Also there is less activation of AMPK (5'-Adenosine Mono Phosphate activated Protein Kinase) in T2DM that also causes decreased formation of thyroid hormones. ${ }^{8}$ Decrease levels of thyroid hormones cause increased TSH release from anterior pituitary gland by feedback mechanism ${ }^{10,13,17}$. Most of the T2DM patients were obese who might have increased level of leptin. This increased level of leptin develops leptin resistance centrally that causes decreased formation of thyroid hormones and increase TSH secretion by feedback mechanism in $\mathrm{T}^{2} \mathrm{DM}^{8}$.

Moreover the binding affinity of $\mathrm{TT}_{4}$ is increased in T2DM that causes decrease formation of $\mathrm{FT}_{4}$ in blood ${ }^{13,17}$. In T2DM, Thyroid Hormone Binding Inhibitor (THBI) also produces that inactivates extra thyroidal conversion enzyme $\left(\mathrm{T}_{4-5}{ }^{\prime}\right.$ - deiodinase $)$. By this way, reduce conversion of $\mathrm{TT}_{4}$ to $\mathrm{TT}_{3}$ in target tissue ${ }^{18,19}$. There is also the degradation rate of $\mathrm{TT}_{3}$ is more than $\mathrm{TT}_{4}$ in $\mathrm{T} 2 \mathrm{DM}$. These all factors are responsible for decrease $\mathrm{T}_{3}$ level ${ }^{3,13}$. T2DM are also associated with obesity, stress, infection that caused changes in hypothalamo-pituitarythyroid axis lead to decrease level of thyroxine and triiodothyronine and increased TSH level in $\mathrm{T}^{2} \mathrm{DM}^{8}$.
In the present study, the hypothyroidism developed in some of newly diagnosed T2DM patients may be due to alteration in hypothalamopituitary-thyroid axis that may cause decreased formation of thyroid hormones. The lower level of free $\mathrm{T}_{4}$ in blood in T2DM may develop due to increase binding affinity of $\mathrm{T}_{4}$. All these factors may cause decrease thyroid hormone levels and increase TSH release by feedback mechanism.

\section{Conclusion}

From this study it can be concluded that hypothyroidism may develop in newly diagnosed T2DM. Therefore routine examination of serum $\mathrm{TSH}, \mathrm{TT}_{4}$ and $\mathrm{TT}_{3}$ may be helpful to prevent complications like hypothyroidism in newly diagnosed T2DM.

\section{Conflict of interest None}

\section{Acknowledgement}

Authors are thankful to the authority of the Department of Physiology and the Department of Endocrinology, Rangpur Medical College, Rangpur and Diabetic Association, Rangpur, for their nice cooperation during sample collection.

\section{Author Affiliations}

1. *Sajeda Afrin, Lecturer, Department of Physiology, Rangpur Medical College, Rangpur. email: sajedaafrin82@gmail.com. Cell: +8801763800898

2. Chandra Rani Sarkar, Professor and Head, Department of Physiology, Rangpur Medical College, Rangpur.

3. A.T.M Zoadur Rahim Zahid, Associate Professor, Department of Physiology, Rangpur Medical College, Rangpur.

4. Neaz Ahmed, Assistant Professor and Head, Department of Biochemistry, Rangpur Medical College, Rangpur.

*For correspondence

\section{References}

1. Hall JE. Insulin, Glucagon, and Diabetes Mellitus. In: Hall JE, editor. Guyton and Hall Text Book of Medical Physiology. $12^{\text {th }}$ ed. Philadelphia Pennsylvania; Saunders publications: 2011. p.950952.

2. Tagoe EA, Azasu H, Annan DA, Ababio GK, AsareAnane H, Aryee NA. Evaluation of thyroid profile 
in Ghanaian patients with type 2 diabetes. Int J Adv Res 2014; 2: 602-9.

3. Vinu V, Chitnis P, Gupta VK. Evaluation of thyroid dysfunction among type II diabetes mellitus. Int $\mathrm{J}$ Pharm Biol Sci 2012; 2:150-55.

4. Rahman M, Rahim A, Nahar Q. Prevalence and risk factors of type 2 diabetes in an urbanizing rural community of Bangladesh. J of Bangl Med Res Conn Bul 2007; 33: 48-54

5. Taksali R, Bindu SM, Mulay S. Evaluation of Thyroid Dysfunction in Type II Diabetes Mellitus: A Case Control Study. Int Jcurr Med and Appl Sciences 2013; 1: 16-20.

6. Barret KE, Barman SM, Boitano S, Brooks HL. Ganong's Review of Medical Physiology. 24 ${ }^{\text {th }}$ ed. New Delhi: Tata McGraw Hill Education Private Limited; 2012. 339p.

7. Singh P, Khan S, Mittal RK. Evaluation of thyroid dysfunction among type-2 diabetic mid and far western Nepalese population. J Coast Life Med 2014; 2(11): 903-6.

8. Swami RM, Kumar N, Srinivasa K, Manjunath GN, Byrav PDS, Venkatesh G. Evaluation of hypothyroidism as a complication in Type II Diabetes Mellitus. J Biomed Res 2012; 23(2):170-

9. Nima V, Thakkar, Jain SM. The impact of diabetes on thyroid dysfunction and outcomes in a native Indian female population. J Thy Sci 2011; 6(4): $1-9$
10. Hage M, Mira S, Zantout MS, Azar ST. Thyroid disorders and diabetes mellitus. J Thy Res 2011; 10: $2-7$.

11. Bruits CA, Ashwood ER. Teitz Fundamentals of clinical chemistry. 5th ed. Philadelphia: W.B. Saunders Company; 2001. 444p.

12. Young DS, Pestaner LC, Gibberman V. Effects of Drugs on Clinical Laboratory Tests. Clin Chem 1975; Apr 21(5): 1D432D.

13. Bharat, Hijam D, Gangate D, Lalnunpui, Premchand, Devi I et al. Thyroid status in diabetes mellitus. J Glycomics Lipidomics 2013; 3:106.

14. Islam S, Yesmin S, Khan SA, Alam NH, Islam SA. Comparative study of thyroid hormone levels in diabetic and non-diabetic patients. SouthEast Asian J Trop Med Public Health 2008; 39(5): 913-6.

15. Al-kazzaz FF, Hussein AAR. Clinical study for thyroid status in type 2 diabetes mellitus patients. DJPS 2012;8(1); 1-9.

16. Udiong CEJ, Udoh AE, Etukudoh ME. Evaluation of thyroid function in diabetes mellitus in Calabar, Nigeria. J Clin Bio 2007; 22(2): 74-8.

17. Rai S, Kumar AJ, Prajna K, Shetty SK, Rai T, Shrindhi et al. Thyroid Function in Type 2 Diabetes Mellitus and in Diabetic Nephropathy. J Clin Diagn Res 2013; 7(8): 1583-5.

18. Pasupathi P, Bakthavathsalam G, Saravanan G, Sundaramoorthi R. Screening for thyroid dysfunction in the diabetic/non-diabetic population. Thyroid Science 2008; 3(8): 1-6.

19. Kumar RA, Narasimhasetty KR, Lalitha R, Shetty SB. Prevalence of thyroid dysfunction among type 2 diabetes subjects in south India. J Clin Invest 2014; 5 : 93-100. 